\title{
Gaya Kepemimpinan KH. Agus Ahmad Syihabudin dalam Pengelolaan Pesantren Darul Ihsan
}

\author{
Nurjaman $^{1 *}$ Irfan Sanusi ${ }^{2}$, Herman $^{3}$ \\ ${ }_{1}^{1}$ Jurusan Manajemen Dakwah, Fakultas Dakwah dan Komunikasi, UIN Sunan Gunung Djati \\ Bandung \\ 2Jurusan Manajemen Dakwah, Fakultas Dakwah dan Komunikasi, UIN Sunan Gunung Djati \\ Bandung \\ *Email: Hafidzaka993@gmail.com
}

\begin{abstract}
ABSTRAK
Tujuan dalam penelitian ini yaitu untuk mengetahui dan memahami bagaimana tipe kepemimpinan dan proses penyusunan kebijakan serta bentuk program yang dilakukan oleh Pondok Pesantren Darul Ihsan yang berada di Desa Dano Kecamatan Leles Kabupaten Garut. Penelitian ini menggunakan metode deskriptif kualitatif. Metode tersebut digunakan untuk mempelajari mengenai latar belakang keadaan sekarang dan interkasi lingkungan suatu unit sosial: individu, kelompok, lembaga atau masyarakat. Adapun hasil dari penelitian ini meliputi tipe kepemimpinan yang dimiliki KH. Agus Ahmad Syihabudin adalah tipe kepemimpinan demokrasi. Sedangkan, proses keputusan induced merupakan proses keputusan yang dilakukan beliau. Keputusan induced itu sendiri adalah suatu keputusan yang didahului dengan cara menganalisis data, fakta serta informasi dan mempertimbangkan situasi dan kondisi. Selanjutnya dalam penetapan programprogram di pesantren, beliau menetapkan kebijakan programnya mlalui musyawarah.
\end{abstract}

Kata Kunci : Gaya; Kepemimpinan; dan Pondok Pesantren.

\section{ABSTRACK}

The purpose of this study was to study and learn how leadership and policy-making processes were made by the Darul Ihsan Islamic Boarding School located in Dano Village, Leles District, Garut Regency. The method used in this research is qualitative descriptive method. The method used to discuss current background and environmental interactions on social units: individuals, groups, institutions or communities. From the results of research issued by the type of leadership possessed by K.H. Agus Ahmad Syihabudin is a type of democratic leadership. Whereas, the induced decision process is the process of his decision. The induced decision itself is a decision that is preceded by analyzing data, facts and information and consideration of situations and conditions. Furthermore, in the determination of programs in the pesantren, he establishes the policies of his program through deliberation

Keywords: Style, Leadership; and Islamic Boarding Schools; 


\section{PENDAHULUAN}

Keberhasilan seorang pemimpin, tidak luput dari gaya kepemimpinan pemimpin tersebut yang dapat mempengaruhi pengikutnya. gaya kepemimpinan itu sendiri secara umum terbagi kedalam dua jenis yaitu otoriter dan demokrasi. Setiap pesantren memiliki ciri khusus akibat perbedaan selera kiai dalam hal memimpin. Hal itu terjadi dikarenakan pesantren tersebut merupakan amal usaha mandiri seorang kiai yang di bantu oleh murid, keluarga bahkan masyarakat sekitar. Sehingga dalam skala nasional sangat jarang terjadi penyeragaman pesantren. (Qomar, 1993: 16).

Cara pengambilan keputusan yang tepat dan kebijakan yang diambilnya juga sangat tepat dengan kondisi dan situasi organisasi, sehingga program yang dijalankannya berjalan dengan sesuai rencana yang diharapkan. Begitupun juga Lembaga Pondok Pesantren Darul Ihsan keputusan atau kebijakan yang diambil akan menentukan masa depan lembaganya. Bangkit atau terpuruknya lembaga tersebut tergantung kepada keputusan yang akan diambilnya. Inti daripada segala macam manajemen adalah kepemimpinan, tanpa pengendalian dari seorang pemimpin keadaan atau situasi secara efektif tidak akan ada tujuan kerja yang bisa tercapai, apalagi secara efesien. Maka dari itu, seorang pemimpin dan cara kepemimpinannya penting bagi suatu lembaga khususnya Lembaga Pondok Pesantren dalam pengelolaan lembaga tersebut.

Pondok Pesantren Darul Ihsan berdiri sejak tahun 1991 dengan nama pendirinya KH. Zaenal Musthafa. Tujuan didirikannya pondok pesantren ini untuk mencetak generasi-generasi ulama yang berilmu, jujur, intelek, dan paling utama berakhlak mulia kepada Allah SWT. Saat pendirian awal pondok pesantren Darul Ihsan merupakan pondok pesantren yang sederhana yang terdiri dari satu mesjid yang di buat dengan kayu sederhana dan asrama putra yang minimalis. pondok pesantren Darul Ihsan selain sebagai lembaga dakwah juga sebagai lembaga pendidikan yang siap untuk mencetak santri-santrinya menjadi sosok yang diharapkan oleh masyarakat.

KH. Ahmad Agus Syihabudin merupakan menantu dari pendiri pondok pesantren tersebut sekaligus pemimpin pondok tersebut setelah KH. Zaenal Musthafa dan beliau memiliki pengaruh cukup tinggi di masyarakat. Dalam menjalankan kepemimpinannya, beliau sangat tegas, disiplin, dan juga bijaksana dalam setiap mengambil suatu keputusan. Hal ini terlihat dari cara beliau mengambil suatu keputusan dan memberikan arahan dan motivasi terhadap para santri dan para staf pengajarnya termasuk kepada warga sekitarnya. Gaya kepemimpinan, program yang dijalankan, dan keputusan-keputusan yang diambil oleh KH. Ahmad Agus Syihabudin dalam mengelola pesantren tersebut sangat baik, sehingga hasil dari keputusan tersebut banyak memberikan nilai-nilai positif untuk memajukan Pondok Pesantren Darul Ihsan. Oleh karena itu dengan 
Gaya Kepemimpinan K.H. Agus Ahmad Syihabudin dalam Pengelolaan Pesantren Darul Ihsan kelebihan yang dimiliki beliau dan kemajuan pondok pesantren Darul Ihsan, peneliti tertarik untuk meneliti lebih lanjut terkait dengan gaya kepemimpinan $\mathrm{KH}$. Agus Ahmad Syihabbudin dalam pengelolaan pondok pesantren Darul Ihsan.

Hasil penelitian terdahulu yang berhubungan dengan penelitian ini. Pertama, penelitian tentang "Gaya dan Tipologi Kepemimpinan Kiai di Pondok Pesantren Babussalam Dusun Kalibening, Desa Tanggalrejo, Mojoagung, Jombang" menyatakan bahwa gaya kepemimpinan yang dilaukan adalah gaya kepemimpinan religio-paternalistic, sedangkan tipologi kepemimpinan kiai di pondok pesantren Babussalam meliputi empat dimensi, yaitu community leader, intellectual leader, spiritual leader, dan juga pemimpin administrative. Perbedaan dengan penelitian ini terdapat dalam variable penelitian yang digunakn yaitu tipolgi serta objek yang diteliti (Sari, 2013: 253).

Kedua, penelitian mengenai’Gaya Kepemimpinan Kyai Lukama Al-Karim dalam pengembangan Lembaga Pendidikan Islam (Studi Kasus di Pondok Pesantren Bahrul Maghfiroh Malang)" menyatakan bahwa Kiai Lukman memiliki gaya kepemimpinan yang karismatik, transformasional, dan visioner. (Rusmini, 2015: 497). Ketiga, penelitian dengan judul "Hubungan Gaya Kepemimpinan Kepala Madrasah dengan Kinerja Guru di Madrasah Aliyah Pondok Pesantren AlIkhlas Ujung Bone" dalam penelitian ini disimpulkan bahwa; (1) gaya kepemimpinan kepala madrasah berada pada kategori baik dengan persentase sebesar 82,25\%; (2) kinerja guru berada pada kategori tinggi dengan persentase sebesar 84,21\%; dan (3) korelasi antara gaya kepemimpinan kepala madrasah dengan kinerja guru menunjukkan korelasi positif yang berada pada tingkat hubungan rendah dengan nilai koefisien korelasi sebesar 0,292. Adapun perbedaan dengan penelitian ini yaitu metode yang digunakan yaitu kuantitatif, sedangkan dalam penelitian ini menggunakan metode kualitatif (Paizal, 2019: 21).

Berdasarkan pemaparan latar belakang diatas, maka dapat membuat fokus penelitian sebagai berikut: (a) Tipe kepemimpinan seperti apa yang diterapkan oleh K.H. Ahmad Agus Syihabudin dalam pengelolaan Pondok Pesantren Darul Ihsan? (b) Bagaimana cara pengambilan keputusan K.H. Ahmad Agus Syihabudin dalam pengelolaan Pondok Pesantren Darul Ihsan? (c) Bentuk Kebijakan Programprogram apa saja yang sudah dijalnkan oleh K.H. Ahmad Agus Syihabudin dalam melaksanakan tugas kepemimpinannya dalam pengelolaan Pondok Pesantren Darul Ihsan?

Metode yang digunakan dalam peneliatian ini yaitu metode deskriptif kualitatif. Metode tersebut digunakan untuk mempelajari mengenai latar belakang keadaan sekarang dan interkasi lingkungan suatu unit sosial: individu, kelompok, lembaga atau masyarakat. Selain itu, penulis juga menuliskan secara umum situasi sosial yang terjadi selama penelitian ini berlangsung dengan tujuan hasil penelitian tersebut lebih realistis dan terpercaya dengan menganalisis hasil wawancara dan observasi mengenai gaya kepemimpinan K.H. Agus Ahmad Syihabudin. 


\section{LANDASAN TEORITIS}

Kepemimpinan itu suatu pertumbuhan alami dari orang-orang yang berserikat untuk suatu tujuan dalam suatu kelompok, (George dan Leslie, 1992: 192). Kepemimpinan dalam pengertian umum adalah suatu proses yang dimiliki seseorang untuk memimpin (directs), membimbing (guides), memengaruhi (influences) atau mengontrol (controls) pikiran, perasaan, atau tingkah laku orang lain. Kepemimpinan adalah kepribadian yang memancarkan pengaruh, wibawa sedemikian rupa sehingga sekelompok orang mau melakukan apa yang dikehendakinya, (Kayo, 2005: 7). Secara umum gaya kepemimpinan dikenal dua gaya, pertama, gaya otoriter yang merupakan suatu gaya yang menggunakan kekuatan jabatan serta kedudukan dalam melaksanakan tugasnya sebagai pemimpin. Kedua, gaya demokratis yang menggunakan kemampuan seseorang dan keikutsertaan anggota dalam pemecahan masalah dan pengambilan keputusan. (Pasolog, 2013: 36).

Pengertian gaya kepemimpinan yaitu berbagai kegiatan yang dilakukan seorang pemimpin untuk mempengaruhi serta mengarahkan bawahannya. Tipe Kepemimpinan Otoriter yaitu tipe yang sangat memaksakan, sangat mendesakkan kekuasaanya kepada bawahan. Tanpa musyawarah, tidak mau menerima saran dari bawahan) mementingkan diri sendiri daripada kelompok, selalu memerintah, memberikan tugas mendadak, cenderung menyukai bawahan yang ABS (asal bapak senang) sikap keras terhadap bawahan. Tipe Kepemimpinan Demokratis yaitu tipe yang bersikap tengah antara memaksakan kehendak dan memberi kelonggaran kepada bawahan. Tipe kepemimpinan ini menempatkan manusia sebagai faktor utama dan terpenting dalam setiap organisasi. Kepemimpinan tipe ini sangat mementingkan musyawarah, yang diwujudkan pada setiap jenjang dan di dalam unit masing-masing. Adapun ciri-ciri gaya demokratis ini yaitu, pendapatnya fokus pada hasil musyawarah, tenggang rasa, memberi kesempatan pengembangan karier bawahan, selalu menerima kritik bawahan, menciptakan suasana kekeluargaan, mengetahui kekurangan dan kelebihan bawahan.

Pengambilan keputusan adalah suatu pendekatan yang sistematis terhadap suatu masalah yang dihadapi, (Pasolog, 2013: 155). Sedangkan definisi keputusan berarti pilihan yaitu pilihan dari dua atau lebih kemungkinan alternatif. Sedangkan menurut Stoner keputusan adalah pemilihan dari beberapa alternatif. Penjelasan Stoner mengandung tiga pengertian, yaitu pilihan atas dasar logika/pertimbangan, ada beberapa alternatif yang harus dan dipilih salah satu yang terbaik, dan ada tujuan yang ingin dicapai dan keputusan ini makin mendekatkan pada tujuan tersebut, (Pasolog, 2013: 165).

Keputusan yang diambil adalah berdasarkan pada keadaan lingkungan atau kondisi yang ada, seperti kondisi pasti, kondisi beresiko, kondisi tidak pasti, dan kondisi konflik. Dasar-dasar Pengambilan Keputusan, Terry menyebutkan ada 
Gaya Kepemimpinan K.H. Agus Ahmad Syihabudin dalam Pengelolaan Pesantren Darul Ihsan lima dasar dari pengambilan keputusan yang berlaku secara umum, yaitu Insting, pengambilan keputusan yang dilakukan dengan berdasarkan atas insting yang bersifat subjektif, sehingga mudah terkena oleh beberapa pengaruh. Pengalaman, pengambilan keputusan yang berdasarkan pada pengalaman, karena pengalaman seseorang dapat memprediksi keadaan suatu berdasarkan pengalaman yang telah dialami. Fakta, pengambilan keputusan berdasarkan fakta, keputusan yang berdasarkan fakta dapat melahirkan keputusan yang baik. Karena dengan fakta maka tingkat kepercayaan terhadap pengambil keputusan dapat lebih tinggi. Wewenang, pengambilan keputusan berdasarkan wewenang biasanya dilakukan oleh pimpinan terhadap bawahannya atau orang yang lebih tinggi jabatannya kepada orang orang yang lebih rendah kedudukannya. Rasional, pengambilan keputusan berdasarkan rasional, keputusan yang dihasilkan bersifat objektif dan logis sehingga dapat dikatakan keputusan yang dihasilkan mendekati kebenaran atau sesuai dengan apa yang diharapkan (Pasolog, 2013: 160-161).

Pesantren adalah Lembaga Pendidikan Islam yang sudah berdiri sejak ratusan tahun yang lalu. Di lembaga inilah diajarkan dan didikkan ilmu dan nilainilai agama kepada santri. Unsur-Unsur Pondok Pesantren sekurang-kurangnya memiliki beberapa unsur yaitu kyai, santri, masjid, dan asrama tempat tinggal santri. Ada lima elemen utama pesantren yaitu pondok, masjid, santri, kyai, dan pengajaran kitab-kitab klasik, (Madjid, 2002: 105). Sebagai Lembaga Dakwah, bahwa semenjak berdirinya pesantren adalah merupakan penyebaran agama Islam baik dalam masalah aqidah atau syari'ah yang ada di Indonesia (Daulay, 2007: 26).

\section{HASIL DAN PEMBAHASAN}

Pondok Pesantren Darul Ihsan terletak di Kampung Tambakbaya Desa Dano Kecamatan Leles Kota Garut. Pondok Pesantren Darul Ihsan terletak di lokasi dekat pegunungan dan persawahan yang subur dan asri, dimana ketersediaan air sangat melimpah yang menjadi sumber utama dalam kehidupan sehari-hari di pondok. Tak heran banyak santri baik dari dalam maupun dari luar betah tinggal pondok tersebut. Dengan letak yang mudah dijangkau, Pondok Pesantren Darul Ihsan hanya berjarak kurang lebih $1 \mathrm{~kg}$ meter dari jalan utama, sehingga untuk memasuki pondok tersebut tidak begitu sulit, walaupun orang tua santri yang mau mendaftarkan anaknya untuk menjadi santri Pondok Pesantren Darul Ihsan tidak akan kesulitan, karena Pondok Pesantren Darul Ihsan sangat terkenal di daerah tersebut bahkan di kampung tetangga pun sudah tidak asing lagi nama Pondok Pesantren Darul Ihsan. Sedangkan letak geografis Pondok Pesantren Darul Ihsan (Skripsi, Aliffahrini, 2011: 17). (a) Sebelah Utara: Desa Jangkurang (b) Sebelah Selatan: Gunung Guntur. (c) Sebelah Timur: Kecamatan Kadungora (d) Sebelah Barat: Majalaya.

Latar belakang didirkannya Pondok Pesantren Darul Ihsan karena keadaan pendidikan yang masih rendah di Desa Dano khususnya dalam pendidikan agama 
sangat minim, sehingga KH. Agus Ahmad Syihabudin dan dibantu oleh keluarganya untuk mendirikan Pondok Pesantren Darul Ihsan untuk belajar bagi anak-anak yang berada di sekitar wilayah Desa Dano Kec. Leles. Keberadaan Pondok Pesantren Darul Ihsan bukan hanya dilatar belakangi oleh pendidikan saja, melainkan masyarakat di wilayah tersebut yang mayoritasnya umat Islam, sehingga beliau beserta keluarganya ingi mendirikan sebuah pondok dan asrama bagi santri yang mau mengaji di pondok tersebut. Selain itu juga, didirikanya Pondok Pesantren tersebut dikarenakan faktor ekonomi (Skripsi, Aliffahrini, 2011: 1).

Bagi anak-anak atau masyarakat yang kurang mampu dalam segi ekonominya untuk membangun sebuah pendidikan, maka Pondok Pesantren Darul Ihsan memberikan fasilitas bebas biaya. Sedangkan kapan berdirinya masjid tersebut tidak ada yang tahu, karena masjid dan tanahnya itu merupakan sebuah wakaf yang sudah lama, yang diberikan oleh masyarakat. Sedangkan pada saat itu yang memegang Masjid Al-Ihsan adalah KH. Al-Musthofa. Pada saat itu, struktur bangunan masjid tidak semegah yang sekarang, dulu masjid tersebut hanya berupa bangunan yang sederhana yang terbuat dari bilik-bilik dari bambu. Sedangkan pada saat itu yang memegang Masjid Al-Ihsan adalah KH. Al-Musthofa. Pada saat itu, struktur bangunan masjid tidak semegah yang sekarang, dulu masjid tersebut hanya berupa bangunan yang sederhana yang terbuat dari bilik-bilik dari bambu (wawancara dengan KH. Agus Ahmad Syihabudin pada tanggal 1 Mei 2018.)

Setelah kedatangan seorang santri yang bernama Ahmad Syihabudin ke masjid tersebut, maka berdirilah sebuah pesantren. Sebenarnya kedatangan beliau hanya sekedar numpang istirahat di masjid, karena perjalanan yang lumayan jauh beliau menyusuri pegunungan hanya untuk meneduh saja. Beliaupun menginap beberapa hari disana dan mengajarkan ngaji kepada anak-anak di masjid. Pada saat itu anak-anak yang mengaji sekitar 3-5 orang. Karena kepedulian beliau terhadap pendidikan agama, maka KH. Al-Musthafa tertarik pada beliau sehingga akhirnya ia menikah dengan putrinya. Selang beberapa bulan, beliau dan istrinya berinisitaif untuk mendirikan sebuah Pondok Pesantren dengan modal tekad yang kuat dan dengan modal seadanya. Maka berdirilah pondok tersebut dengan banguanan yag sederhana. Pondok tersebut didirikan pada tanggal 25 Maret 1991. Kemudian pondok tersebut diberinama dengan mengambil nama masjid Al-Ihsan menjadi Darul Ihsan. Maka berdirilah Pondok Pesantren Darul Ihsan. Profil Pondok Pesantren Darul Ihsan. Nama Pondok Pesantren: Darul Ihsan, Tingkat: Umum, Nomor Statistik: 51.2.32.07.22.277, Nama Pengasuh/Pembina: KH. Ahmad Syihabudddin, S.Pd. I, Nama Ketua Pengurus: Dadan Ahmad Zaini Dahlan, Lc, Tahun Berdiri: 25 Maret 1991, Alamat: Kp. Tambakbaya Ds. Dano, Leles, Status Tanah: Wakaf (Bukti terlampir), Luas Tanah: $\pm 14000 \mathrm{~m} 2$, Nomor Rekening: 0578658756, An Yayasan Al-Mustofa Tambakbya, Nama Bank: BNI, NPWP: 21.031.468.8-443.000, Kontak: 082315477901 (Dokumen Pondok Pesantren 
Darul Ihsan, 2018).

Gaya Kepemimpinan K.H. Agus Ahmad Syihabudin dalam Pengelolaan Pesantren Darul Ihsan

Program dan Kegiatan Lainnya: (a) Program reguler: Pengajian kitab kuning, Kajian Al-Qur'an (Tahsin, tilawah, tafsir dan tahfidh), Kajian Islam komprehensif, Student Leadership Development, Brigade mesjid, Kajian Umum ASWAJA, Muhadlarah, Majelis ta'lim Jum'at dan Minggu, Latihan bahasa Arab dan Inggris. (b) Kegiatan Insidental : peringatan hari besar Islam, peringatan hari besar nasional, Beladiri karate, pelatihan tataboga, kursus komputer, broadcasting radio dan jurnalistik, latihan desain grafis dan fotografi, pembinaan kesenian, karawitan dan angklung, hadrah, marawis, gambus dan qasidah, paduan suara dan marching band (Dokumen Pondok Pesantren Darul Ihsan, 2018.)

Visi adalah gambaran masa depan yang realitas, dapat dipercaya, dan menarik bagi kelanjutan dan perkembangan suatu organisasi (Timotius, 2016: 40). Adapun visi dan misi Pondok Pesantren Darul Ihsan yaitu sebagai berikut: Visi: Terwujudnya generasi muslim yang alim dan amil serta berakhluk karimah. Misi: Menyelenggarakan pendidikan formal, informal, dan nonformal. Menyediakan sarana dan prasarana penunjang pembelajaran, Melaksanakan program pembinaan dan pengembangan kewirausahaan yang terintegrasi, Membina dan mengembangkan pola kerjasama dan hubungan kemasyarakatan (Dokumen Pondok Pesantren Darul Ihsan, 2018).

Sarana maupun prasarana memiliki keterkaitan yang sangat penting sebagai alat penunjang keberhasilan suatu proses yang dilakukan. Dengan demikian, suatu proses kegiatan yang akan dilakukan tidak akan dapat mencapai hasil yang diharapkan sesuai dengan rencana, jika sarana dan prasaran tidak tersedia. Sarana adalah segala sesuatu yang dapat dipakai sebagai alat dalam mencapai maksud atau tujuan tertentu. Contohnya, sarana pendidikan diartikan sebagai alat untuk mencapai tujuan pendidikan sperti buku, pulpen, komputer, dan lain-lain. Sedangkan prasarana adalah segala sesuatu yang merupakan penunjang utama terselenggaranya suatu proses (usaha, pembangunan, dan proyek). Seperti lokasi, bangunan, kantin, lapangan, dan lain-lain. Jadi sarana lebih ditujukan untuk alat atau benda-benda yang bergerak sedangkan prasarana lebih ditujukan untuk alat atau benda-benda yang tidak dapat bergerak. Adapun sarana dan prasarana Pondok Pesantren Darul Ihsan yaitu: Masjid yang berada di area pondok memiliki satu lantai, dibagi menjadi dua, di depan untuk santru putra dan di belakng untuk santri putri. Luas Masjid 14x28 m yang dibangun atas di atas luas tanah kurang lebih $337 \mathrm{~m}^{2}$. Masjid ini selain digunakan untuk tempat shalat digunakan juga sebagai tempat sarana untuk mengaji kitab dan muhadharah dan pengajian rutinan setiap hari Minggu dan ba'da Jumat (Aliffahrani, 2011: 32).

Aula adalah salah satu ruangan yang sangat peting di sebuah instansi pendidikan atau sekolah, selain fungsi aula itu sendiri yang bisa bermacam-macam, bisa digunakan sebagai tempat rapat atau ruang pertemuan, bisa juga sebagai tempat pentas seni dan olahraga. Aula yang ada di Pondok Pesantren Darul Ihsan 
masih menggunakan ruangan kelas, karena untk pembuatan aula masih dalam proses perencanaan pembuatan. Adapun kelas yang suka di jadikan sebagai tempat pertemuan menggunakan ruangan kelas yang dekat dengan kantor atau masjid (Dokumen Pondok Pesantren Darul Ihsan 2018).

Gedung Asrama putera puteri di Pesantren Darul Ihsan ada dua asrama, asrama pertama buat santri putra yang lokasinya dekat dengan masjid dan kantor sekolah, dimana asrama putra ada 12 kamar dan 1 dapur, 5 kamar di bawah dan 5 kamarnya lagi di atas dan 2 kamar nya berada di dalam dekat dengan dapur. Sedangkan untuk asrama putri lokasinya ada dua, satu dekat dengan rumah KH. Agus ahmad Syihabudin dimana asrama tersebut ada 11 kamar, yang 5 didepan dekat kolam yang 5 lagi di belakang, sedangkan yang satu lagi ada di atas, namun kamar yang satu ini luas sekali, karena dulunya sebagai ruangan kelas untuk belajar, sehingga ruangan tersebut hanya diskat oleh beberapa papan untuk dijadikan sebuah kamar. Sedangkan untuk asrama yang satunya lagi tepatnya di pinggir masjid yang berada dibawah sekaligus bersatu dengan dapur santri putri. Gedung Madrasah merupakan gedung tempat dimana proses belajar mengajar dilaksanakan (Dokumen Pondok Pesantren Darul Ihsan).

Pada siang hari gedung tersebut digunakan untuk belajar sekolah tergantung dengan waktu yang diberikan. Karena kelas tersebut bergantian dipakai oleh kelas TK, SD, SMP, dan SMA. Kalau pada malam hari kelas tersebut ramai dipakai untuk pembelajaran kitab dan pelajaran agama yang lainnya. mulai dari selepas shalat magrib sampai jam setengah delapan. Pembagian kelas pun dibagi-bagi, ada yang teras masjid buat anak-anak, ada juga yang di kelas buat yang sudah besar. Pembagian kelas disesuaikan dengan kelas sekolah pagi hari. Jadi semuanya diperkelas, guru-gurunya pun berbeda-beda. Setelah mereka beres mengaji dari kelas, mereka balik ke masjid untuk melanjutkan pengajian berikutnya yang akan di pimpin oleh KH. Agus Ahmad Syihabudin dan semua kelas disatukan baik yang senior maupun yang jenior. sebagai tempat pertemuan menggunakan ruangan kelas yang dekat dengan kantor atau masjid (Dokumen Pondok Pesantren Darul Ihsan 2018).

Adapun gedung madrasah yang ada di Pondok Pesantren Darul Ihsan ada 4 gedung. Gedung pertama 2 lantai berada di dekat masjid, gedung kedua, ketiga dan keempat ada di belakang gedung pertama, jarak antara gedung pertama, kedua, ketiga, dan keempat sekitar kurang lebih $100 \mathrm{~m}$. Gedung kedua dua tingkat, gedung ketiga satu tingkat, dan gedung keempat masih tahap pembangunan (Wawancara dengan pengurus pesantren Bapak Iyan pada tanggal 03 Mei 2018).

Lapangan Olahraga yang ada di Pondok Pesantren Darul Ihsan merupakan tempat dimana para santri maupun para siswanya melakukan serangkaian kegiatan-kegiatan, ada yang bermain sepak bola, basket, tenis meja, latihan keteranpilan baris beraris (LKBB), dan lain-lain. Adapun lapangan olahrga yang ada di pondok tersebut ada dua, yang pertama di depan masjid dan dekat kantor 
Gaya Kepemimpinan K.H. Agus Ahmad Syihabudin dalam Pengelolaan Pesantren Darul Ihsan sekolah sedangkan yang satunya lagi ada di belakang Gedung kedua f) Kendaraan operasional yang ada di Pondok Pesantren darul Ihsan merupakan kendaraan yang beroprasi untuk kegiatan-kegiatan santri atau para guru, dan keluarga pesantren jika ada undangan dari luar seperti undangan marawis undangan pernikahan dan lain sebagainya, maka menggunakan kendaraan yang disediakan oleh pesantren (Dokumen Pondok Pesantren Darul Ihsan 2018).

Jumlah Santri PonPes Darul Ihsan Tahun 2017-2018. a) Madrasah Diniyah, putra 40 dan putri 20 b) Santri Takhossus, putra 75 dan putri 60 c) Raudhatul Athfal, putra 16 dan putri 9 d) Madrasah Ibditaiyah, putra 93 dan putri 117 e) Madrasah Stnawiyah, putra 156 dan putri 121 f) Madarasah Aliyah, putra 78 dan putri 62 g) Malis Ta'lim, putra 300 dan putri 200. Jadi total secara keseluruhan jumlah santri dan jama'ah yang ada di pondok pesantren Darul Ihsan adalah 1347 orang. Program-program Pondok Pesantren Darul Ihsan. Program regular, Pengajian kitab kuning, Kajian Al-Qur'an (Tahsin, tilawah, tafsir dan tahfidh), Kajian Islam komprehensif, Student Leadership Development, Brigade masjid, Kajian Umum ASWAJA, Muhadlarah, Majelis ta'lim Jum'at dan Minggu , Latihan bahasa Arab dan Inggris, Kegiatan Insidental, Peringatan hari besar Islam, Peringatan hari besar Nasional, Beladiri karate, Pelatihan tataboga, Kursus komputer, Broadcasting radio dan jurnalistik, Latihan desain grafis dan fotografi , Pembinaan Kesenian, Karawitan dan angklung, Hadrah, Marawis, Gambus dan Qasidah, dan Paduan Suara dan Marching Band.

Struktur Organisasi dan Deskripsi Pekerjaan. Dalam surah al-Shaff ayat 4 dikemukakan: Artinya: "Sesungguhnya Allah menyukai orang yang berperang dijalan-Nya dalam barisan yang teratur seakan-akan mereka seperti suatu bangunan yang tersusun kokoh". Maksud dari shaff disitu menurut Al-Qurtubi adalah menyuruh masuk dalam sebuah barisan (organisasi) supaya terdapat keteraturan untuk mencapai tujuan. Dalam sebuah hadits diterangkan: Artinya: "Sesunggubnya Allah mencintai orang yang jika melakukan suatu pekerjaan dilakukan dengan "tepat, terarah dan tuntas". Suatu pekerjaan apabila dilakukan dengan teratur dan terarah, maka hasilnya juga akan baik. Maka dalam suatu organisasi yang baik, proses juga dilakukan secara terarah dan teratur atau. Maka dari itu, pembagian tugas dalam sebuah organisasi sangatlah penting guna memperlancar suatu tujuan. Adapaun struktur organisasi di Pondok Pesantren Darul Ihsan yaitu: Struktur Kepengurusan Pondok Pesantren Darul Ihsan. Pembina, Ketua: KH. Ahmad Syihabudin, S.Pd.I, Anggota: KH. Zaenal Mustofa, Hj. Solihah Fauziya dan Rahma Anisatul Masriyah. Pengurus, Ketua Umum: Dadan Ahmad Zaini Dahlan, Lc, sekertaris umun: Hendra Permana, S.Pd.I., Ceng Nurodin, H. Enjang Abdul Manan, bendahara: Maman Sihabudin, S.Pd.I. Pengawas, Ketua: Agus Suhendar, anggota: Rudiman.Adapun tugas yang diamantakan Pondok Pesantren Darul Ihsan dari masing-masing pengurus adalah; Pembina, terdiri dari ketua dan anggota, tukas ketua ini merupakan pengasuh umum pondok pesantren. Pengasuh 
pimpinan ini diketuai oleh KH. Agus Ahmad Syihabudin dimana beliau bertugas untuk menyusun program pengajian, menysun kepungurusan pesantren, membuat rancangan, membuat suatu keputusaan, melakukan pembagian tugas terhadap pengurus, berwenang untuk mengubah anggaran dasar, dan lain sebagainya.

Adapun anggotanya hanya bertugas sebagai pembantu pemimpinnya, dimana ketika anggota dibutuhkan maka para anggota harus siap menerima tugas dari pimpinannya. Pengurus, terdiri dari ketua, sekertaris, bendahara dan para anggota. Ketua pengurus ini tidak lain adalah anak dari KH. Agus Ahmad Syihabudin yang bernama Dadan Ahmad Zaini Dahlan, tugas ketua dalam hal ini adalah untuk mengelola sekolah, masjid, mengangkat dan memberhentikan pelaksana suatu kegiatan, bertanggung jawab atas anggaran dan rencana kerja kepada pembina dan lain sebagainya. Maka apa-apa keperluan pondok pesantren pengurus inilah yang menjalankan program dan kebijakan dari ketua pembina yaitu dari K.H. Agus Ahmad Syihabudin. Sedangkan bendahara bertugas sebagai pengelola keuangan pesantren, dimmana bendahara hanya menerima, menyimpan, membayarkan, menatausahakan, dan mempertanggung-jawabkan uang untuk keprluan belanja pondok pesantren. Sedangakn sekertaris betugas mengelola administrasi dalam hal cata mencatat seprti mambuat surat, menerima tamu, menyimpan arsip, menyusun serta membuat jadwal kegiatan pembelajaran.Pengawas, adalah orang orang yang bertugas melakukan pengawasan dan memberi nasihat kepada pengurus dalam menjalankan tugasnya di pondok pesantren, pengawas berhak mengetahui segala tindakan yang dijalankan oleh pengurus, dan pengawas juga berhak memberhentikan untuk sementara pengurus, apabila pengurus tersebut bertindak bertentangan dengan anggaran dasar.

\section{Tipe Kepemimpinan KH. Agus Ahmad Syihabudin}

Tipe atau gaya kepemimpinan merupakan teknik seseorang dalam menjalankan kepemimpinannya, dengan berusaha mempengaruhi perilaku orang-orang yang dikelolanya. KH. Agus Ahmad Syihabudin merupakan seorang pemimpin yang mempunyai wawasan yang luas, ide, dan gagasan-gagasan yang mudah diterima oleh banyak orang, selain dengan gayanya yang memikat banyak orang, beliau juga mampu membina dan memberikan teladan dalam mewujudkan membangun dan membinan gagasannya. Nama KH. Agus Ahmad Syihabudin sudah tidak asing lagi di daerah tersebut, bahkan daerah tetanggapun banyak yang mengetahui sosok KH. Agus Ahmad Syihabudin.

Dalam menjalankan kepemimpinannya, KH. Agus Ahmad Syihabudin tidak akan terlepas dari gaya kepemimpinan yang menjadi kebiasaannya untuk mengelola lembaganya. Tipe kepemimpinan yang diterapkan oleh KH. Agus Ahmad Syihabudin tidak lain adalah tipe kepemimpinan demokratis. Dikatakan demokratis karena beliau selalu memperhatikan bawahnannya dalam 
Gaya Kepemimpinan K.H. Agus Ahmad Syihabudin dalam Pengelolaan Pesantren Darul Ihsan melaksanakan tugas yang dibebankan pada bawahannya, menciptakan suasana kekeluargaan, adil, bijaksana dan terbuka.

Beliau juga menerima pendapat dari bawahannya apabila ada kekeliruan dalam memutuskan suatu keputusan mengenai sebuah program atau kegiatan lainnya dan beliau juga mengharapkan saran dari para dewan guru dan pengurus masjid yang lainnya. Seperti ketika beliau mau membuat skema tentang pembangunan gedung sekolah, beliau juga minta pendapat dari ahli bangunan bagaimana tentang hasil gambarannya ada yang mesti dirubah atau tidak. Juga ketika beliau lagi sibuk di luar, segala urusan pesantren ia berikan tanggung jawabnya kepada guru-guru yang ada di sana, untuk menggantikan sementara selama dirinya di luar. Bukan itu saja, tatkala pembuatan jadwal pengajian beliau juga sebagian tugas diserahkan kepada para pengurus untuk menentukan jadwal pelajaran, itu juga dibarengi dengan pengawasan beliau.

\section{Pengambilan Keputusan KH. Agus Ahmad Syihabudin}

Salah satu tugas pokok pemimpin yang menjadi rutin dalam birokrasi publik adalah Pengambilan keputusan. Proses pengambilan keputusan yang dilakukan itu lebih efektif jika dibandingan dengan proses pelaksanaan kegiatan teknis. Pondok Pesantren Darul Ihsan merupakan lembaga pendidikan dan merupakan bagian lembaga dakwah, maka tidak heran kalau ada kesamaan dengan organisasi atau lembaga lain dalam proses ini. Karena pengambilan keputusan adalah salah satu bagian dari rangkain proses yang mesti dijalankan oleh sebuah lembaga. Hal ini dilakukan untuk memajukan program-program organisasi sehingga terwujudnya organisasi yang maslahat.

Untuk mengambil sebuah keputusan sangat dipengaruhi oleh karakteristik dan tipe yang dimiliki oleh seorang pemimpin. Pembuatan keputusan merupakan bagian terpenting dari seorang pimpinan, terutama dalam melaksankan fungsi perencanaan. Dalam proses perencanaan, pemimpin memutuskan tujuan organisasi yang akan dicapai, sumber-sumber data yang akan digunakan dan siapa yang akan melaksanakannya dalam hal tugas yang dibutuhkan. Dalam proses pengambilan keputusan ini biasanya akan dirumuskan menjadi sebuah kebijakan organisasi tersebut dan dilaksanakan dalam program-program yang tersusun secara sistematis dan dilaksanakan secara bersama sesuai dengan pekerjaannya masing-masing. Sedangkan kebijakan adalah rangkaian kegiatan yang dilaukan beberapa pihak dengan tujuan tetentu agar menjadi acuan untuk diikuti serta dilaksanakan untuk memecahakan suatu permasalahan.

Banyak ragam dari keputusan yang akan diambil oleh sipembuat keputusan, diantaranya keputusan induced. Keputusan induced itu sendiri adalah suatu keputusan yang didahului dengan cara menganalisis data, fakta serta informasi dan mempertimbangkan situasi dan kondisi. Dalam pembuatan keputusan KH Agus Ahmad Syihabudin senantiasa mengambil keputusan dengan bermusyawarah, sebagai media untuk mengambil dan menetapkan sebuah keputusan dan hasil

Tabligh: Jurnal Manajemen Dakwah Vol. 3 No. 3 (2018) 207-222 
keputusan itu akan menjadi sebuah kebijakan yang akan diterapkan oleh pesantren tersebut. Tentunya pengambilan keputusan itu dengan melihat sebuah fakta yang ada di lapangan dalam hal ini melihat kondisi dan situasi para anggotanya (santri dan pengurus). Walaupun beliau menyertakan pertimbangan pribadinya tidak menjadi masalah, karena hal ini bukan semata-mata untuk kepentigan pribadinya melainkan untuk kemaslahatan bersama. Hal itu disebabkan peran dan kredibilitas beliau lebih banyak dipercaya oleh pengurus atau bawahannya untuk menetapkan sebuah keputusan untuk kemajuan pondok pesantrennya. Jadi, keputusan ini mula-mula dari beliau kemudian dimusyawarahkan kepada pengurus-pengurus pesantren, meskipun keputusan berada ditangan beliau pada akhirnya, tetap saja keputusan itu harus hasil musyawarah bersama dilihat dari banyak dan sedikitnya manfaat untuk kemajuan Pondok Pesantren Darul Ihsan.

Dalam menetapkan suatu keputusan atau kebijakan yang diterapkan oleh Pondok Pesantren Darul Ihsan berpegang pada kebersamaan dalam adanya musyawarah untuk mencapai kata mufakat. Disamping itu pula KH. Agus Ahmad Syihabudin dalam memutuskan suatu kebijakannya juga mempertimbangkan beberapa hal, diantaranya: Tujuan utama dibuatnya sebuah keputusan dan fungsi utama keberadaan pondok pesantren: Kebutuhan apa saja yang akan santri perlukan untuk masa depan mereka, Kondisi santri dan para staf gurunya (kemampuan dan latar belakang mereka), Kondisi dan sarana pondok pesantren yang bisa mendukung keputusannya terhadap kebijakan yang akan diputuskannya. Dengan adanya perumusan dan pertimbangan disegala aspek termasuk kebutuhan santri dan guru-gurunya, sarana yang ada di pondok pesantren diharapkan dapat menunjang dalam proses penyusunan kebijakan yang akan dilaksanakan.

Dengan proses penyusunan sebuah keputusan atau kebijakan dengan tepat, KH. Agus Ahmad Syihabudin mampu mengembangkan dan menyelaraskan sistem pendidikan formal dan informal, dengan adanya perluasan dan penambahan sarana dan prasarana seperti pembanguan berbagai gedung belajar untuk segala aktivitas para santri dan gurunya dalam membina ilmu, khususnya ilmu agama, seperti memperluas bangunan masjid dibesarkan, banguan sekolah buat penambahan kelas, membuat dapur untuk para santrinya, membangun kamar mandi, menyediakan air bersih dan lain-lain.

\section{Kebijakan Program KH. Agus Ahmad Syihabudin Dalam Pengelolaan Pondok Pesantren Darul Ihsan}

Pondok Pesantren Darul Ihsan dengan tradisi keilmuan yang dikembangkan telah mencoba menerapkan suatu tatanan pendidikan dengan memadukan antara pendidikan formal dengan pendidikan agama dan umum. Pendidikan formal dan non formal yang dikembangkan di Pondok Pesantren Darul Ihsan telah diformulasikan yang sejajar dan saling melengkapi, sehingga tolak ukur keberhasilan santri tidak dilihat dari hasil yang dicapai dalam proses pendidikan 
Gaya Kepemimpinan K.H. Agus Ahmad Syihabudin dalam Pengelolaan Pesantren Darul Ihsan formal saja juga dengan pendidikan nonformal.Pengembangan sistem pendidikan Pondok Pesantren Darul Ihsan diwujudkan melalui gabungan pendidikan formal, pendidikan umum, dan pendidikan agama.

Jadi, KH. Agus Ahmad Syihabudin selaku pimpinan pondok pesantren mengkulturasikan antara sistem salaf (tradisional) dengan sistem khalaf (modern). Hal isi sesuai dengan visi misin K.H. Agus Ahmad Syihabudin. Sistem salaf yang diakultualisasikan di dalam lembaga non formal yaitu di pondok pesantren. Kitab salaf merupakan salah satu mata bidang wajib bagi yang menjadi pelajaran utamanya. Sedangkan sistem khalaf diterapkan di dalam lembaga pendidikan formal yaitu di sekolah.Pondok Pesantren Darul Ihsan merupakan pesantren yang mayoritas santrinya adalah siswa sekolah, artinya hampir seluruh santri menuntut ilmu di sekolahyang dekat dengan pesantren, meskipun begitu yang menjadi pembelajaran utamanya tetap pendidikan agama. Karena motto beliau adalah "Dengan seni hidup menjadi indah, dengan ilmu hidup menjadi mudah, dengan iman hidup menjadi terarah".

Pondok Pesantren Darul Ihsan merupakan bagian lembaga yang berbasis lembaga dakwah, oleh karena itu, Pondok Pesantren Darul Ihsan diyakini akan mencetak kader-kader intelektual islami yang siap terjuan dan mengamalkan ilmunya kepada masyrakat, negara, dan khusunya pada diri sendiri, demi mencapai kemeslahatan bersama. Dalam upaya meningkatkan santri dan para gurunya, pola pengembangan dan pembinaan pendidikan Pondok Pesantren Darul Ihsan yaitu: Membina dalam mengembangakan pendidikan melalui lembaga dakwah, Membina yang dikembangkan melalui ekstrakulikuler yang disesuaikan dengan kebutahan santri dan masyarakat, Membina yang dikembangkan melalui pendidikan formal dan informal dalam rangka mempercepat proses pencerdasan kehidupan santri.

Selain pembinaan di atas ada juga pembinaan yang sesuai dengan misinya yaitu Menyelenggarakan pendidikan formal, informal, dan nonformal, Menyediakan sarana dan prasarana penunjang pembelajaran, Melaksanakan program pembinaan dan pengembangan kewirausahaan yang terintegrasi, Membina dan mengembangkan pola kerjasama dan hubungan kemasyarakatan. Dengan demikian kegiatan santri terutama dalam merumuskan satuan aktivitas santri dan para gurunya, tentu berbeda dengan menyiapkan pola kegiatan yang ditetapkan dibeberapa sekolah umum. Berdasarkan kebijakan tersebut, sebagai oprasional dari program yang merupakan keputusan atau kebijakan pondok pesntren, maka KH. Agus Ahmad Syihabudin merealisasikan programnya, diantaranya: Menetapkan Perekrutan Anggota Santri Baru, Setiap tahun ajaran baru, otomatis banyak santri atau siswa yang masuk untuk mendaftarkan dirinya sebagai santri di Pondok Pesantren Darul Ihsan, dan itu merupakan salah satu syarat untuk menjadi anggiota santri pada umumnya melalui pendaftaran, setelah itu para santri baru harus mengikuti mabastiq yaitu masa anggota santri baru. 
Adapun kegiatan mubastiq diantaranya adalah pengenalan pondok pesantren, pengenalan terhadap guru-guru ngaji dan guru-guru sekolah, pengenalan kepada pengurus pondok pesantren, dan juga pengenalan terhadap kegiatan-kegiatan yang akan dilaksanakan setelah menjadi santri. Menetapkan Kegiatan Mubadlarah, Muhadlarah merupakan kegiatan yang wajib diikuti oleh semua santri tanpa terkecuali, karena dengan adanya kegiatan ini para santri dilatih dalam hal mental dan kemampuan yang ada pada dirinya, meskipun mereka tidak punya kemampuan apapun, tetap meraka akan dibimbing dan dilatih untuk menjadi kader-kader yang terbaik untuk masa mendatang.

Adapun kegiatan muhadarah ini dilaksanakan pada hari rabu malam kamis, mulai dari sehabis shalat isya sampai selesai, paling malam sampai jam 10 malam. Adapun tugas kegiatan muhadarah ini di antaranya, Menjadi MC atau pembawa acara, Pembacaan ayat suci Al-quran, Pembacaan shalawat, Tawashulan atau pembacaan doa tahlilan, ceramah atau pidato bahasa Indonesia, bahasa arab, dan bahasa Inggris, kegiatan hiburan, seperti marawisan, drama santri, dan lain-lain. Menetapkan Kegiatan Membaca Berjanji, kegiatan ini sudah tidak akan asing lagi bagi pesantren-pesantren pada umumnya, kegiatan berjanji ini dilaksanakan pada malam jumat setelah shalat isya samapai jam 9 malam. Dimana pembaca berjanji sebelumnya dijadwal terlebih dahulu oleh petugasnya. Pembaca berjanji dilaksanakan oleh 5-8 orang santri putra dan santri putri. Pengembanagan Seni dan Keterampilan, selanjutnya berupa, seni ilmu bela diri seperti karate, seni baca al-quran, marawisan, kasidahan, bermain gamelan, dan lain-lain. KH. Agus Ahmad Syihabudin tidak mewajibkan para santri untuk mengikuti kegiatan ini, siapa saja yang amu dipersilahkan mengikutinya sedangkan yang tidak maupun tidak apaapa. Kegiatan jasmani ini dilakukan pada hari minggu pada pagi hari dengan larilari di jalanan atau lari pagi.

\section{PENUTUP}

Setelah melihat tipe kepemipinan, proses penyusunan kebijakan, dan bentuk program, bahwa peneliti sepakat kepemimpinan yang dijalankan oleh KH. Agus Ahmad Syihabudin adalah gaya kepemimpinan demokratis ini dapat dilihat dari berbagai indikasi yang dapat menguatkan kedudukannya sebagai pemimpin yang demokratis yaitu Tipe Kepemimpinan KH. Agus Ahmad Syihabudin, Gaya atau tipe atau model merupakan bawaan dari diri seseorang atau pemimpin dalam menjalankan tugasnya sebagai pemimpin, KH. Agus Ahmad Syihabudin merupak seorang pemimpin yang mempunyai tipe kepemimpinan yang demokratis, dikatakan demokratis karena beliau selalu memperhatikan bawahnannya dalam melaksanakan tugas yang dibebankan pada bawahanny, juga menerima pendapat dari bawahannya apabila ada kekeliruan dalam memutuskan suatu keputusan sebuah program atau kegiatan lainnya dan beliau juga mengharapkan saran dari para dewan guru dan pengurus masjid yang lainnya. 
Gaya Kepemimpinan K.H. Agus Ahmad Syihabudin dalam Pengelolaan Pesantren Darul Ihsan

Pengambilan keputusan yang diambil KH Agus Ahmad syihabudin adalah berdasarkan pada keadaan lingkungan atau kondisi yang ada di lingkungan pesantren baik itu santri atau banguannnya, seperti kondisi pasti, kondisi beresiko, kondisi tidak pasti, dan kondisi konflik yang terjadi. Setelah proses pengambilan keputusan ini lalu dirumuskan menjadi kebijakn suatu lembaga maupun organisasi dan program yang tersusun serta sitematis dalam pelaksanaannya. Banyak ragam dari keputusan yang akan diambil oleh sipembuat keputusan, diantaranya keputusan induced. Keputusan induced itu sendiri adalah suatu keputusan yang didahului dengan cara menganalisis data, fakta serta informasi dan mempertimbangkan situasi dan kondisi.

Dalam pembuatan keputusan KH Agus Ahmad Syihabudin senantiasa mengambil keputusan dengan bermusyawarah, sebagai media untuk mngambil dan menetapkan sebuah keputusan dan hasil keputusan itu akan menjadi sebuah kebijakan yang akan diterpkan oleh pesntren tersebut. Tentunya pengambilan keputusan itu dengan melihat sebuah fakta yang ada di lapangan dalam hal ini melihat kondisi dan situasi para anggotanya (santri dan pengurus). Walaupun beliau meyertakan pertimbangn pribadinya tidak menajdi masalah, karena hal ini bukan semata-mata untuk kepentigan pribadinya melainkan untuk kemaslahatan bersama. Bentuk Kebijakan Program KH. Agus Ahmad Syihabudin, Sebuah keputusan akan menjadikan sebuah kebijakan yang baru untuk dipergunakan atau ditaati oleh bawahannya, pengembangan sistem pendidikan Pondok Pesantren Darul Ihsan diwujudkan melalui gabungan pendidikan formal, pendidikan umum, dan pendidikan agama.

KH. Agus Ahmad Syihabudin mengkulturasikan antara sistem salaf (tradisional) dengan sistem khalaf (modern). Sistem salaf yang diakultualisasikan di dalam lembaga non formal yaitu di pondok pesantren. Kitab salaf merupakan salah satu mata bidang wajib bagi yang menjadi pelajaran utamanya. Sedangkan sistem kalaf diterapkan di dalam lembaga pendidikan formal yaitu di sekolahberdasarkan kebijakan tersebut, sebagai oprasional dari program yang merupakan keputusan atau kebijakan pondok pesntren, maka KH. Agus Ahmad Syihabudin merealisasikan programnya, diantaranya; (a) menetapkan perengkrutan anggota santri baru; (b) menetapkan kegiatan muhadarah; (c) menetapkan kegiatan membaca berjanji, mengembangan seni dan keterampilan, menetapkan pembuatan jadwal pelajaran kitab kuning, pengajian rutinan bagi masyarakat setiap seminggu sekali, menetapkan untuk melaksanakn arisan qurban.

\section{DAFTAR PUSTAKA}

Aliffahrini. (2011). Perkembangan Pondok Pesantren Darul Ihsan Tambak Baya Des. Dano Kec. Leles Kab. Garut Tabun 1991-2008, Jurusan Sejarah dan Peradaban Islam, UIN SGD Bandung.

Allolangi, Y. (2012) Kepemimpinan Transformasional sebagai Kepemimpinan Dakwah. 
Nurzaman, I. Sanusi, Herman

Ilmu Dakwah: Academic Journal for Homiletic Studies [Online], 6.1.

Daulay, H.P. (2007). Pendidikan Islam, Jakarta : Kencana

Kayo, K.P. (2005). Kepemimpinan Islam dan Dakwah, Padang: Amzah

Madjid. (2002). Masyarakat Religius, Jakarta : Paramadina

Paizal I, Siraj A, \& Mania S, (2019). Hubungan Gaya Kepemimpinan Kepala Madrasah dengan Kinerja Guru di Madrasah Aliyah Pondok Pesantren Al-Ikblas Ujung Bone.

Al-Thariqah: Jurnal Pendidikan Islam 4(1).

Pasolog, H. (2013). Kepemimpinan Birokrasi, Bandung: CV. Alfabeta.

Qomar, M. (1993). Pesantren, Jakarta: PT. Gelora Aksara Pratama.

Rusmini, (2015). Gaya Kepemimpinan Kyai Lukama Al-Karim dalam pengembangan Lembaga Pendidikan Islam (Studi Kasus di Pondok Pesantren Bahrul Maghfiroh Malang Analisis: Jurnal Studi Keislaman UIN Lampung 15(2).

Sari, B.I \& Yani, M.T. (2013). Gaya dan Tipologi Kepemimpinan Kiai di Pondok Pesantren Babussalam Dusun Kalibening, Desa Tanggalrejo, Mojoagung, Jombang. Kajian Moral dan Kewarganegaraan, 2(1).

Timotius, (2016). Kepemimpinan dan Kepengikutan, Yogyakarta: CV Ando Offest. 